\title{
TFE3: A helix-loop-helix protein that activates transcription through the immunoglobulin enhancer $\mu \mathrm{E} 3$ motif
}

\author{
Holger Beckmann, Li-Kuo Su, ${ }^{1}$ and Tom Kadesch \\ Howard Hughes Medical Institute and the Department of Human Genetics, University of Pennsylvania School of Medicine, \\ Philadelphia, Pennsylvania 19104-6072 USA
}

\begin{abstract}
The $\mu \mathrm{E} 3$ motif within the immunoglobulin heavy-chain enhancer is required for full enhancer activity and is known to bind one, or perhaps a family, of related ubiquitous nuclear proteins. Here, we present the isolation of a cDNA that encodes an apparently novel $\mu E 3$-binding protein designated TFE3. The major open reading frame of the cDNA predicts a protein of $59 \mathrm{kD}$, with a leucine zipper situated adjacent to an myc-related motif that has been proposed to assume a helix-loop-helix structure. Both of these motifs have been shown (for other proteins) to facilitate protein-protein interactions and DNA binding. Expression of the cDNA in 3T3 cells stimulates transcription from an artificial promoter consisting of four $\mu \mathrm{E} 3$ sites linked to a TATA box and also augments transcription of a reporter gene when it is linked to multiple copies of a particular heavy-chain enhancer subfragment but not when it is linked to the intact enhancer. Using GAL4 fusion proteins, we mapped a strong transcription activation domain within TFE3 that is distinct from the leucine zipper and helix-loophelix motifs and includes a potential negative amphipathic helix. Like the other $\mu E 3$-binding proteins detected in nuclear extracts, in vitro-synthesized TFE3 also binds to the USF/MLTF site found in the adenovirus major late promoter.
\end{abstract}

[Key Words: $\mu \mathrm{E} 3$; DNA-binding proteins; helix-loop-helix motif; immunoglobulin heavy-chain enhancer]

Received September 22, 1989; revised version accepted November 14, 1989.

The immunoglobulin heavy-chain (IgH) enhancer is thought to be crucial for the transcriptional activation of rearranged heavy-chain genes (Banerii et al. 1983; Gillies et al. 1983; Neuberger 1983; for review, see Atchison 1988). In transfection experiments, the IgH enhancer is capable of stimulating transcription from a variety of promoters, but only in cells of the B lineage (the IgH enhancer is also active in several T-cell lines). This activity has been shown to correlate well with the presence of approximately six protein binding sites within the enhancer. Four of these, $\mu \mathrm{E} 1, \mu \mathrm{E} 2, \mu \mathrm{E} 3$ and $\mu \mathrm{E} 4$, were defined initially by in vivo footprinting (Ephrussi et al. 1985; for review, see Calame and Eaton 1988). Two others, octamer (referring to the conserved octanucleotide ATGCAAAT; Singh et al. 1986; Staudt et al. 1986) and $\mu$ EBP-E (Peterson et al. 1988), were defined first by in vitro binding assays. Deletions or mutations of these sites generally reduce overall enhancer activity (Lenardo et al. 1987; Kiledjian et al. 1988; Perez-Mutul et al. 1988; Tsao et al. 1988). Even though activity of the enhancer is restricted to $B$ cells, only one of these sites (octamer) is known to bind B-cell-specific proteins (OTF-2/oct-2, OTF-2b; Landolfi et al. 1986; Staudt et al. 1986; Gerster

'Present address: Cold Spring Harbor Laboratory, Cold Spring Harbor, New York 11724 USA. et al. 1987; Scheidereit et al. 1987; Schreiber et al. 1988| in addition to a ubiquitous protein (OTF-1/oct-1; Fletcher et al. 1987; Sturm et al. 1988). The other sites have been shown to bind only ubiquitous proteins. Specific binding to the $\mu \mathrm{E} 4$ motif has not been detected in vitro. The octamer element cannot account entirely for the B-cell specificity of the enhancer, however, because mutating or deleting it still results in a strong B-cell-specific enhancer (Lenardo et al. 1987; Kiledjian et al. 1988). Furthermore, recent evidence suggests that many different tissues, in addition to B cells, express one or more members of a large family of octa-binding proteins (Scholer et al. 1989a,b). Some reports suggest that the large octa-independent component of IgH enhancer activity is negatively regulated in non-B cells /Wasylyk and Wasylyk 1986; Kadesch et al. 1986; Imler et al. 1987; Weinberger et al. 1988).

One of the enhancer elements bound by a ubiquitous DNA-binding activity is the $\mu \mathrm{E} 3$ site. Studies of mutant enhancers have indicated that this site alone may be responsible for as much as $30 \%$ of the enhancer's activity in B cells (Lenardo et al. 1987; Kiledjian et al. 1988; Perez-Mutul et al. 1988; Tsao et al. 1988). The site was also shown to contribute to the low level of enhancer activity observed in non-B cells (Kiledjian et al. 1988). The corresponding DNA-binding activity, NF- $\mu \mathrm{E} 3$, was 
thought initially to represent a single protein (Sen and Baltimore 1986); however, purification has since revealed perhaps as many as three related proteins of similar size $(42.5-45 \mathrm{kD})$ that interact with the motif in various oligomeric forms (Peterson and Calame 1989), and a related activity has even been described in yeast (Beckmann and Kadesch 1989). For simplicity, we will use the term NF- $\mu \mathrm{E} 3$ to describe the mammalian $\mu \mathrm{E} 3$ binding activity derived from nuclear extracts, which may represent multiple proteins. We have noticed that a DNA sequence that bears remarkable similarity to the $\mu \mathrm{E} 3$ motif is also found in the adenovirus major late promoter. This site in the major late promoter is bound by the transcription factor USF (or MLTF), a $43-$ to $46-\mathrm{kD}$ protein (Chodosh et al. 1986; Sawadogo et al. 1988). In fact, the USF/MLTF-binding site is more related to the $\mu E 3$ site (11 of 12 nucleotides) than the $\mathrm{kE3}$ site within the $\kappa$ light-chain enhancer ( 7 of 7 nucleotides), which is known to bind NF- $\mu$ E3 (Sen and Baltimore 1986). This suggests the interesting prospect that USF/MLTF and NF- $\mu$ E3 activities are related or, perhaps, are one in the same.

As a first step toward developing a general understanding of how cell-type specificity is imposed on apparently ubiquitous DNA-binding proteins and, specifically for the case of the $\mu E 3$ site, to elucidate the relationship between NF- $\mu$ E3 and USF/MLTF, we isolated a cDNA that encodes a $\mu E 3$-binding protein. The encoded protein is almost certainly not USF/MLTF or NF- $\mu E 3$, although it does bind to a USF/MLTF-binding site. Designated transcription factor E3 (TFE3), the encoded protein represents a novel DNA-binding protein that functions as a positive-acting transcription factor. Furthermore, it possesses two structural motifs that may mediate interactions with other proteins.

\section{Results \\ Isolation of a cDNA encoding a $\mu E 3$-binding protein}

To identify cDNAs that encode $\mu \mathrm{E} 3$-binding proteins, we screened a human B-cell-derived $\lambda$ gt $11 \mathrm{cDNA}$ library with labeled oligonucleotides carrying the $\mu \mathrm{E} 3$-binding site (see Methods). We isolated one phage, designated $\lambda 3$, that expressed a $\beta$-galactosidase fusion protein with the ability to bind specifically to the $\mu \mathrm{E} 3$-containing oligonucleotide. As shown in Figure 1A, mobility-shift assays using $\lambda 3$ lysogen extracts detected a slow migrating activity that bound the oligonucleotide carrying the wildtype $\mu E 3$ sequence (WT, lane 5), but not a similar oligonucleotide carrying a 3-base change mutant $\mu \mathrm{E} 3$ site (MUT, lane 6). This specificity was mimicked by two shifted bands found with nuclear extracts of HeLa cells (lanes 7 and 8), and no complex with this specificity was observed with $\lambda$ gtll lysogen extracts (lanes 3 and 4). Western and Southwestern analyses of lysogen extracts resolved by SDS-polyacrylamide gel electrophoresis confirmed that the $\mu \mathrm{E} 3$-binding activity comigrated with a high-molecular-weight $\beta$-galactosidase fusion protein (data not shown).
To explore further the nature of the binding to the $\mu \mathrm{E} 3$ site, we carried out a dimethylsulfate (DMS) interference analysis. Because of the relatively poor binding obtained with the bacterial lysogen extracts, and for convenience, we employed a different fusion protein that was synthesized in vitro. In this case, a segment of the $\lambda 3 \mathrm{cDNA}$ insert was removed from $\lambda$ gt 11 and fused to the first 147 amino acids of the yeast GAL4 protein (GAL4 $\lambda 3-A$ ) in a vector carrying the promoter for SP6 RNA polymerase adjacent to the GAL4 sequences. When this vector was transcribed by SP6 RNA polymerase, and the synthesized RNA was subsequently translated in a reticulocyte lysate, a suitably stable complex could be obtained with a fragment derived from the IgH enhancer (for a representative mobility-shift assay using this protein, see Methods and Fig. 6, lane 17, below). As shown in Figure $1 \mathrm{~B}$, the GAL4 $\lambda 3$-A fusion protein gave a DMS interference pattern coincident with the $\mu \mathrm{E} 3$ site that was nearly identical to that described previously for NF- $\mu \mathrm{E} 3$ activity in nuclear extracts (Sen and Baltimore 1986; Peterson and Calame 1987).

$\lambda 3 c D N A$ encodes a $59-k D$ protein with a leucine zipper adjacent to a putative helix-loop-helix motif related to $c$-myc

The sequence of the 2.5-kb $\lambda 3$ cDNA is shown in Figure 2 . It contains one major open reading frame capable of encoding a protein of $59 \mathrm{kD}$. Southern hybridization confirmed that the cDNA is encoded by the human genome. Northern analysis identified an RNA of $\sim 2.5$ $\mathrm{kb}$ that, in addition to human B cells, is present in a wide variety of cell types (e.g., HeLa cells) and mouse tissues (e.g., liver and kidney; data not shown). Primer extension experiments indicated that the $\lambda 3 \mathrm{cDNA}$ terminates $\sim 150$ nucleotides from the true $5^{\prime}$ end (data not shown). Hence, at present, we cannot say whether the first encoded methionine (position 41) represents the normal site of translation initiation or is internal to the protein. If it is the initiating methionine, the protein would have a calculated molecular weight of $\sim 55 \mathrm{kD}$. Even though the flanking nucleotides of this translation initiation site are not optimal (Kozak 1984), as will be shown below, this AUG does have the capacity to initiate the translation of functional protein in vivo. Examination of the $3^{\prime}$ end of the cDNA failed to reveal an apparent polyadenylation signal or poly(A) tail.

A comparison of the amino acid sequence to those of other DNA-binding proteins and transcription factors revealed three interesting motifs. The first, encompassing amino acids 134-199, is a region that bears a high degree of identity to the myc family of proteins. Initially described in MyoD by Tapscott et al. (1988) as a myc similarity region (MSR), it has been proposed by Baltimore and co-workers (Murre et al. 1989a,b) that certain classes of MSRs define amphipathic helix-loophelix structures that mediate protein oligomerization and DNA binding. The helix-loop-helix structure has been found in several other transcription factors, including MyoD, myogenin, three immunoglobulin en- 

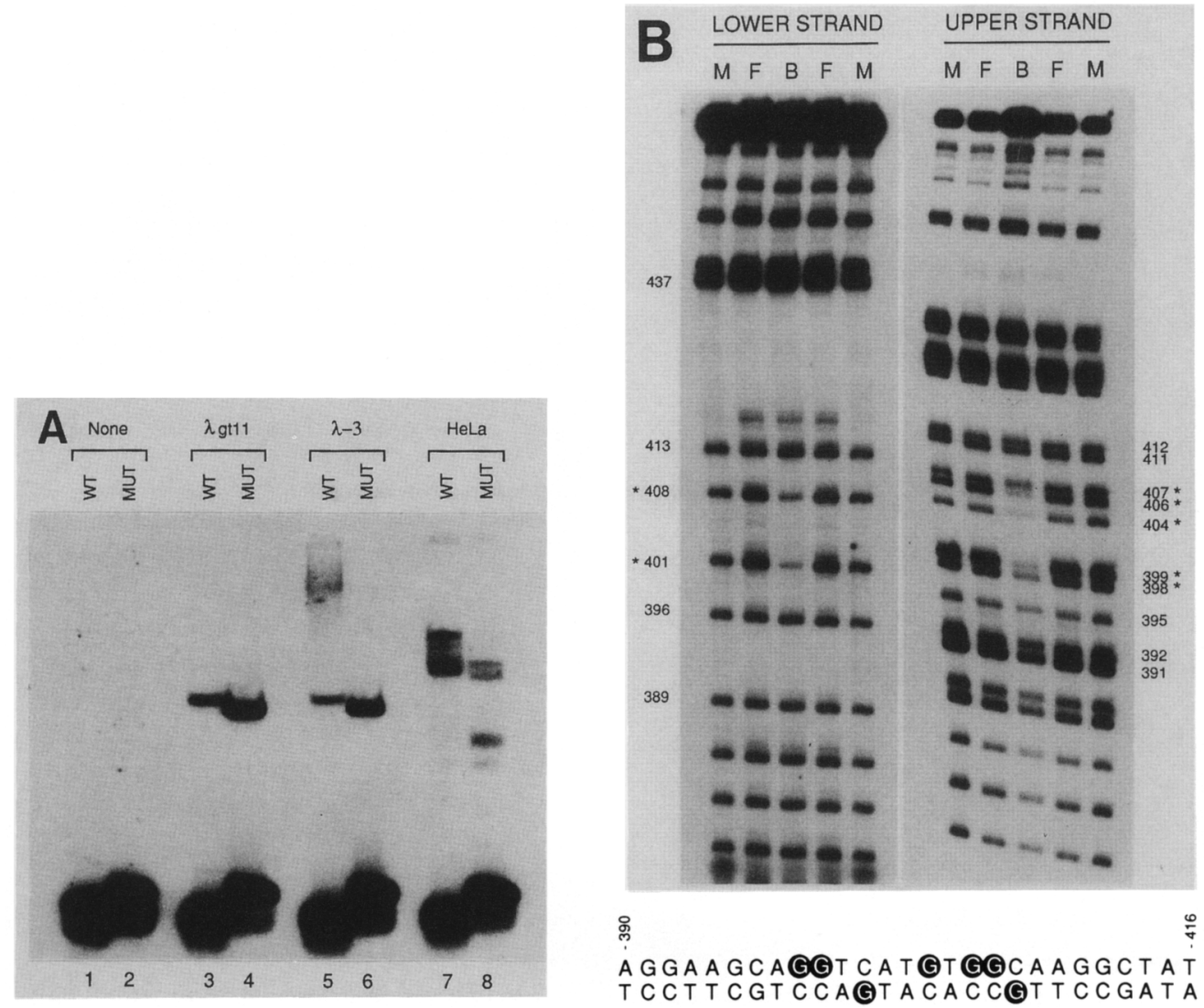

Figure 1. The $\lambda 3$ fusion proteins bind to the $\mu \mathrm{E} 3$ site of the IgH enhancer. $(A)$ Mobility-shift assays using bacterial lysogen extracts and HeLa cell nuclear extracts. Labeled oligonucleotides containing a wild-type (wt) or a mutant (mut) $\mu \mathrm{E} 3$ site were incubated with either no extract (lanes 1 and 2), $\lambda$ gt 11 lysogen extracts (lanes 3 and 4), $\lambda 3$ lysogen extracts (lanes 5 and 6), or HeLa nuclear extracts (lanes 7 and 8$).(B)$ Methylation interference assays employed in vitro-synthesized GAL4 $\lambda 3$-A fusion protein and IgH enhancer fragment 20, as described in Methods. A representative mobility-shift assay with this protein is shown in Fig. 6 (lane 17) below. The free (F) and the bound (B) forms of the lower and upper strand of the a fragment are indicated. Markers were derived from a fragment subjected to a Maxam-Gilbert sequencing reaction. Cleaved guanosine residues are indicated by the numbering system of Gillies et al. (1983). $\left(^{*}\right)$ Guanosine residues that diminish binding when methylated. A summary of the results is presented below the autoradiograph. Points of interference are indicated by circled $G$ residues, which are identical to those described for partially purified murine NF- $\mu$ E3 (Peterson and Calame 1987) and, except for guanosine 398, identical to those described in vivo (Ephrussi et al. 1985) and for NF- $\mu \mathrm{E} 3$ in crude nuclear extracts (Sen and Baltimore 1986).

hancer $\mu E 5 / \kappa E 2$-binding proteins, a recently described gene (1yl-1) adjacent to a chromosome translocation in T-cell acute lymphoblastic leukemia, and several Drosophila genes associated with neuronal development (Tapscott et al. 1988; Mellentin et al. 1989; Murre et al. 1989a; Henthorn et al. 1990). A comparison of myc-related helix-loop-helix sequences of the mammalian proteins (Fig. 3) reveals a remarkable degree of identity and similarity. The second motif predicted by the $\lambda 3$ cDNA sequence is a leucine zipper (Landschulz et al. 1988), and it is situated immediately adjacent to the MSR. It consists of four leucines spaced at 7-amino-acid intervals, beginning at amino acid 202. Leucine zippers have been found in a number of eukaryotic transcription factors and also have been shown to facilitate proteinprotein interactions (e.g., Kouzarides and Ziff 1988, 1989; Gentz et al. 1989; Landschulz et al. 1989). It has been suggested that leucine zippers mediate coiled-coil interactions and can represent a subset of the three-four rule, where every third and fourth amino acid, defining a broad face of an $\alpha$-helix, is hydrophobic $/ \mathrm{O}^{\prime}$ Shea et al. 1989). Consistent with a possible role in mediating such a coiled-coil interaction, the three-four rule is adhered to beginning in the middle and extending slightly beyond the $\lambda 3$ zipper region. The third motif found at the carboxyl end of the $\lambda 3$ protein (amino acids $368-536)$ is a motif defined merely by its being rich in proline residues $(16 \%)$ and arginine residues $(14 \%)$. Although such a region may, by definition, be devoid of structure, a proline-rich region has been shown to define a transcription activation domain in the CCAATbinding factor CTF (Mermod et al. 1989).

The $\lambda 3$ protein activates transcription through artificial and natural $\mu E 3$-binding sites

To test directly whether the $\lambda 3$ protein encodes a transcription factor, we expressed the cDNA in mammalian 


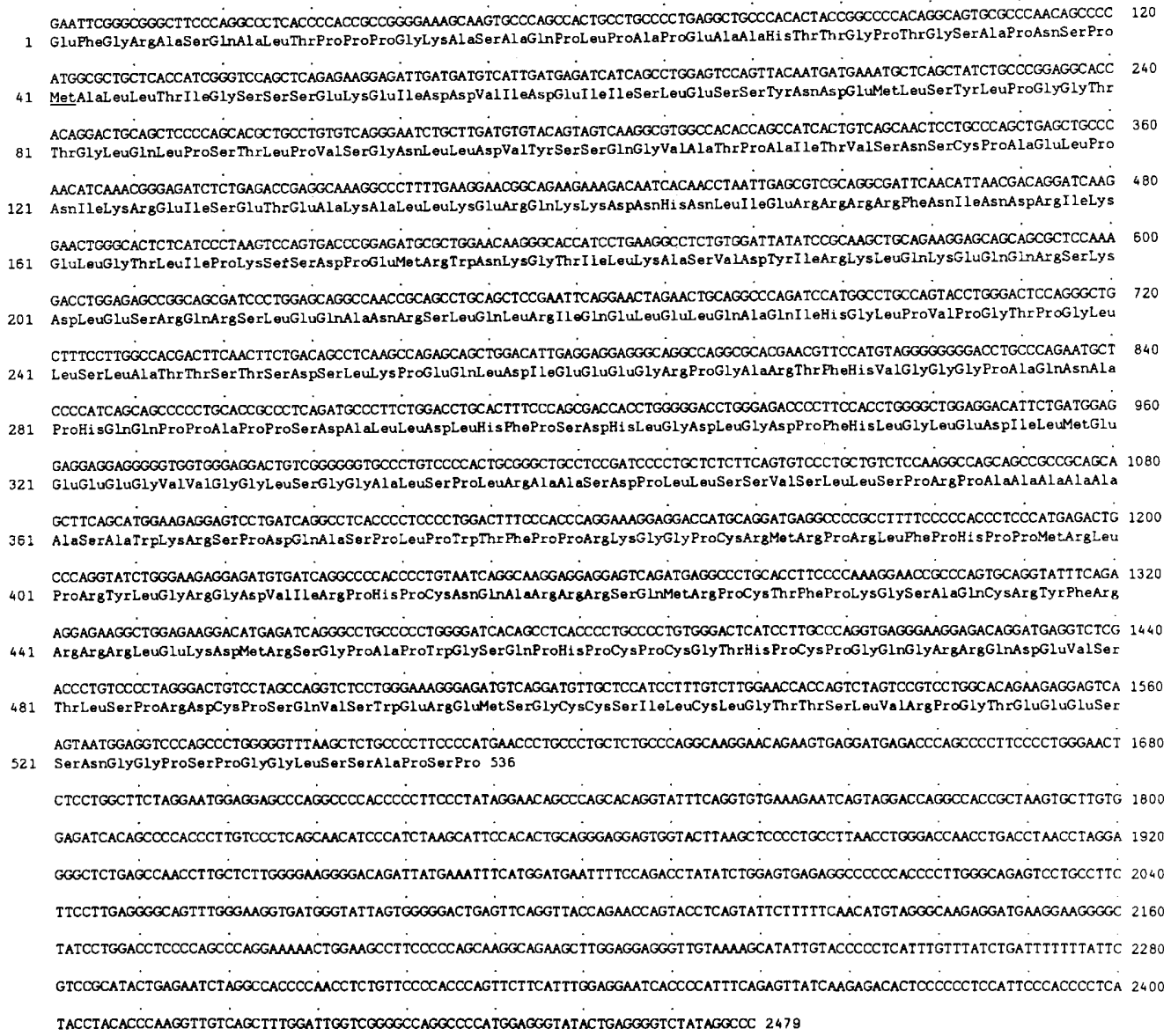

Figure 2. Nucleotide sequence of the $\lambda 3$ cDNA and its deduced amino acid sequence. The first methionine in the sequence is amino acid 41. The myc similarity region (MSR or helix-loop-helix) spans residues 134-199, and the leucine zipper begins at amino acid 202. The proline/arginine-rich region begins at amino acid 368. The EMBL accession number for human TFE 3 is 51330.

cells and measured the response of a reporter gene carrying $\mu \mathrm{E} 3$-binding sites. The plasmid pSV2A- $\lambda 3$ (Fig. 4A) contains the $\lambda 3$ cDNA under control of the SV40 early promoter. The cDNA was inserted in such a way that its expression would rely on translation from its own AUG (amino acid 41 in the open reading frame). Because the cDNA lacked introns and an apparent polyadenylation signal, the SV40 small-t antigen intron and early polyadenylation signals were provided $3^{\prime}$ to the cDNA. Initially, we employed three reporter plasmids. The first contained the TATA box from the liver/bone/kidney alkaline phosphatase gene promoter linked to the bacterial chloramphenicol acetyltranferase (CAT) gene (Weiss et al. 1988). The second linked four tandem copies of the wild-type $\mu \mathrm{E} 3$ oligonucleotide to the TATA box. The third linked four tandem copies of the mutant $\mu \mathrm{E} 3$ oligonucleotide to the TATA box. As shown in Figure 4A, cotransfection of mouse 3T3 cells with increasing amounts of pSV2A- $\lambda 3$, along with the reporter plasmid carrying the normal $\mu \mathrm{E} 3$ oligonucleotides, resulted in increasing levels of CAT activity (lanes 4-6). No activation was observed with the TATA box alone (lanes 1-3) or when the TATA box was linked to oligonucleotides carrying the mutant $\mu \mathrm{E} 3$ sites (lanes $7-9$ ). The max- imum level of stimulation in this experiment gave a CAT activity similar to that obtained with the SV40 early promoter, in which expression of CAT (lane 10) is increased. Low levels of activity are obtained with the normal oligonucleotides in the absence of cotransfected pSV2A- $\lambda 3$ plasmid (cf. lanes 4 and 7). This is attributable to endogenous $\mu \mathrm{E} 3$ transcription factors, possibly related to the $\lambda 3$ protein (D. Ruezinsky and T. Kadesch, unpubl.).

These results demonstrate clearly that the $\lambda 3$-encoded protein can activate transcription through its cognate binding site; therefore we will refer to this protein as transcription factor E3 (TFE3).

The former experiments leave unanswered the question of whether TFE3 can activate transcription via the $\mathrm{IgH}$ enhancer. To address this, we employed three additional reporter plasmids in our transfection experiments. The first contained the human $\beta$-globin promoter linked to the CAT gene (plasmid $\beta$ G-CAT). The second carried 12 tandem copies of a wild-type IgH enhancer (fragment 2) positioned $3^{\prime}$ to the $\beta G$-CAT transcription unit [plasmid $\beta G$-CAT- $(2)_{12}$ ]. The third carried 12 tandem copies of a subfragment of the enhancer (fragment 12) linked to the $\beta G$-CAT transcription unit [plasmid $\beta G$ - 
CAT $(12)_{12}$. Fragment 12 carries only the $\mu E 3$-binding site and the enhancer 'core' sequences (Kadesch et al. 1986). The activity of fragment 12 (and that of related fragments) in non-B cells led to the hypothesis that it was devoid of negative motifs that repressed enhancer activity in non-B cells (Kadesch et al. 1986; Wasylyk and Wasylyk 1986; Weinberger et al. 1988). It has been shown previously that multiple copies of the enhancer can lead to detectable enhancer activity in non-B cells (Kiledjian et al. 1988). Hence, we reasoned that for transfection of $3 \mathrm{~T} 3$ cells, these plasmids bearing multiple enhancers may be more sensitive to trans-activation.

As shown in Figure 4B, cotransfection of 3T3 cells with increasing amounts of pSV2A- $\lambda 3$ and the reporter plasmid carrying fragment 12 led to increased expression from the $\beta G$-CAT transcription unit (lanes 7-9). No activation was observed with reporter plasmids lacking the enhancer (lanes 4-6) or with plasmids carrying the wildtype enhancer (lanes 10-12). Note that in the absence of cotransfected pSV2A- $\lambda 3$, enhancer fragment 12 is more active than enhancer fragment 2 (cf. lanes 7 and 10). Even though the level of TFE3-mediated activation of enhancer fragment 12 was lower than that obtained with the $[\mathrm{E} 3]_{4}$-TATA promoter (lanes $1-3$ ), the effect was reproducible. We were unable to obtain similar results with cotransfections into the B cell line P3-X63Ag8 (data not shown). However, in those experiments, the overall trans-activation potential of even the $[\mathrm{E} 3]_{4}$-TATA promoter was reduced; thus, it is likely that this negative result represented a technical limitation. Hence, we conclude that TFE 3 can activate transcription through the $\mu \mathrm{E} 3$ site in the IgH enhancer in $3 \mathrm{~T} 3$ cells but cannot do so if the intact enhancer is used. This result is consistent with models invoking negative regulation of the enhancer.

Under certain conditions it may be useful to synthesize very high levels of transcription factors. We explored this possibility for TFE3 by creating a plasmid in which TFE3 would autoregulate its own synthesis through a positive-feedback loop. The plasmid pFBE3 contains the $\lambda 3$ cDNA inserted downstream of the $[\mathrm{E} 3]_{4}$-TATA promoter. We determined the ability of pFBE 3 to activate expression of the $[\mathrm{E} 3]_{4}-\mathrm{TATA}$ promoter linked to the CAT gene, and compared this to the activating ability of pSV2A- $\lambda 3$. In the absence of autoregulation, $\mathrm{pFBE} 3$ would be expected to express very low levels of TFE 3 compared to pSV2A- $\lambda 3$ (see Fig. 4A, lanes 4 and 10). However, as shown in Figure 4C, pFBE3 functions as a better activator than pSV2A- $\lambda 3$ (cf. lanes 4 and 5 or lanes 6 and 7). Hence, in cells producing artificially high levels of TFE 3 , the [E3] $]_{4}$-TATA promoter becomes more efficient than the SV40 early promoter.

TFE3 has a strong transcription activation domain in a region that contains a potential negative amphipathic helix

We sought to map the region(s) of TFE3 directly responsible for its ability to activate transcription. To do this we fused either the full-length $\lambda 3$ protein or subregions

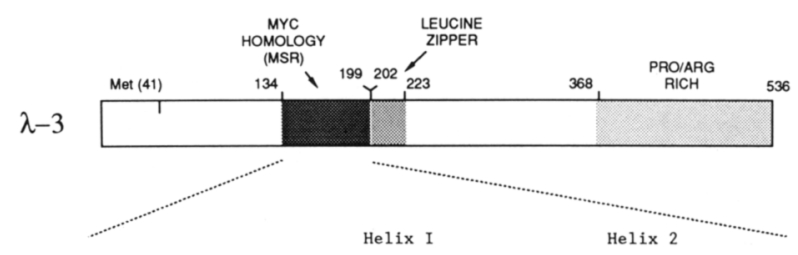

c-MYc NTEENVKRRTHNVLERQRRNELKRSFFALRDQIPELENNEKA-PKVVILKKATAYILSVQAEEQKL

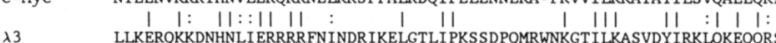

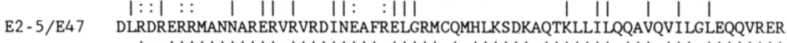

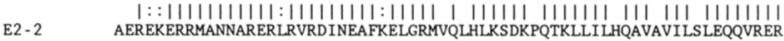
AEREKERRMANNARERLRVRDINEAFKELGRMQLHLKSDKPQTKLLILHQAVAVILSLEQQVRER E12 AEREKERRVANARERLRVRDINEAFKELGRMCQLHLNSEKPQTKLLILHQAVSVILNLEQQVRER

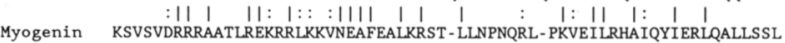

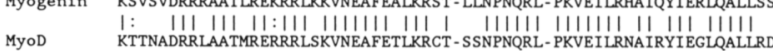

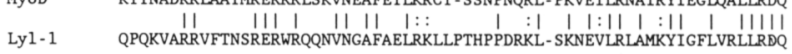

$\begin{array}{clllllllllllllll}\begin{array}{c}\text { Consensus } \\ (7 / 8)\end{array} & \mathrm{R}_{\mathrm{R}} & \mathrm{N} & \mathrm{E}^{\mathrm{R}} & \mathrm{R} & \mathrm{I}_{\mathrm{N}} & \mathrm{F} & \mathrm{E}_{\mathrm{L}} & & \mathrm{K} & \mathrm{K} & \mathrm{IL} & \mathrm{A} & \mathrm{Y}_{\mathrm{I}} & \mathrm{L} & \mathrm{R} \\ & \mathrm{K} & \mathrm{T} & \mathrm{K} & \mathrm{V} & \mathrm{A} & & \mathrm{R} & & & & \mathrm{V} & & \mathrm{Q}\end{array}$

Figure 3. Sequences of MSR (or helix-loop-helix) of various mammalian proteins. (Top) Schematic representation of the $\lambda S$ protein. The relevant regions of the following proteins are shown. Human c-myc (amino acids 341-403; Battey et al. 1983), myogenin (amino acids 76-137; Wright et al. 1989) MyoD (amino acids 104-167; Davis et al. 1987), lyl-1 (amino acids 132-196; Mellentin et al. 1989), and the $\mu E 5 / \mathrm{kE2}$ enhancer-binding proteins E47 and E12 (amino acids 331-395, Murre et al. 1989a), E2-5 (amino acids 474-539; Henthorn et al. 1990) and E2-2 (amino acids 514-579; Henthorn et al. 1990). Identical amino acids are indicated by vertical lines, and conserved amino acids are represented by double dots. The proposed amphipathic helices I and II (Murre et al. 1989a) are indicated. The consensus sequence represents amino acids which are found in seven of the eight possible positions.

to the DNA-binding domain of the yeast GAL4 protein (GAL4 amino acids 1-147; Keegan et al. 1986). Because the truncated GAL4 protein alone cannot activate transcription, the presence of an activation domain is indicated by the ability of the GAL4 fusion protein to mediate transcription activation of a reporter gene through GAL4-binding sites (Keegan et al. 1986; Ma and Ptashne 1987). We obtained three reporter genes for these studies (Lillie and Green 1989). One contains the adenovirus E1B TATA box linked to the CAT gene; the other two contain either one or five copies of a GAL4-binding site linked to the E1B TATA box.

The various GAL4 fusion proteins employed and the results of two representative experiments are summarized in Figure 5A. When the entire open reading frame of the $\lambda 3$ cDNA was fused to the GAL4 DNA-binding domain (GAL4 $\lambda 3$ ) and cotransfected into $3 T 3$ cells with the different reporter plasmids, transcription was stimulated 50- to 100-fold when the reporter plasmids carried GAL4-binding sites. Good activation was seen with a single GAL4-binding site, and this level was not increased when five GAL4-binding sites were used instead of one. This restriction may be attributable to stearic hindrance. No activation of any of the reporter plasmids was seen with the GAL4-binding domain alone 
Figure 4. The $\lambda 3$ protein activates transcription through a $\mu \mathrm{E} 3$ site in vivo. (A) Activation of a promoter containing four copies of the $\mu \mathrm{E} 3$ site. A schematic diagram of the pSV2A- $\lambda 3$ expression plasmid is shown. The $\lambda 3$ sequences that presumably encode protein upon transfection are shown (as in Fig. 3) as wide rectangles (translation initiation begins at Met-41). The noncoding segments of the cDNA are shown as thin rectangles. $t$ and $A_{n}$ represent the positions of the SV40 small-t antigen intron and early polyadenylation signal, respectively. Reporter plasmids $(1 \mu \mathrm{g})$ carrying either a TATA box linked to the bacterial CAT gene (TATA; lanes 1-3), four tandem copies of the wild-type $\mu \mathrm{E} 3$ oligonucleotide linked to TATA-CAT ([E3] $]_{4}-$ TATA; lanes 4-6), or four copies of the mutant $\mu \mathrm{E} 3$ oligonu-

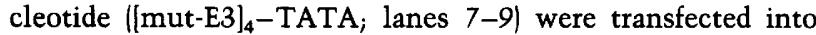
$3 \mathrm{~T} 3$ cells along with the indicated amounts of pSV2A- $\lambda 3$ plus 5 $\mu \mathrm{g} \mathrm{pCH} 110$ and pUC DNA to bring the total amount of transfected DNA to $20 \mu \mathrm{g}$. Cells were harvested and assayed for CATase activity 2 days after transfection. Lane 10 shows the CATase activity obtained from cells transfected with $1 \mu \mathrm{g}$ pSV2Acat, which expresses the CAT gene under control of the SV40 early promoter. $(B)$ pSV2A- $\lambda 3$ stimulates transcription through an IgH enhancer subfragment. Reporter plasmids $(1 \mu \mathrm{g})$ containing the TATA box linked to four $\mu \mathrm{E} 3$ sites $\left([\mathrm{E} 3]_{4}-\right.$ TATA-CAT; lanes $1-3$ ) or carrying the CAT gene linked to the human $\beta$-globin promoter either alone ( $\beta G-C A T$; lanes $4-6$ ) linked to 12 copies of the IgH enhancer fragment 12 positioned $3^{\prime}$ [ $\beta \mathrm{G}-\mathrm{CAT}-(12)_{12}$; lanes 7-9], or linked to 12 copies of enhancer fragment 2 positioned $3^{\prime}$ [ $\beta$ G-CAT- $\left\{\left.2\right|_{12}\right.$; lanes $10-12$ ] were transfected into $3 \mathrm{~T} 3$ cells, along with the indicated amounts of pSV2A- $\lambda 3$, and assayed for CATase as described above. (C) Overexpression of the $\lambda 3$ protein through a positive feedback loop. Reporter plasmids $(0.5 \mu \mathrm{g})$ were transfected into $3 \mathrm{~T} 3$ cells alone (lane 1), or along with the indicated amounts of pSV2A- $\lambda 3$ (lanes 2, 4, and 6) or the positive feedback plasmid pFBE 3 in which the $\lambda 3 \mathrm{cDNA}$ is expressed from a $[\mathrm{E} 3]_{4}$-TATA promoter (lanes $3,5-7)$, and assayed for CATase, as described above.

$\left(\mathrm{GAL}_{1-147}\right)$. The maximum level of stimulation with intact TFE3 was roughly the same as that obtained for a fusion protein of GAL4 and an activating region of the adenovirus E1A protein (GAL4-E1A, E1A amino acids 121-223; Lillie and Green 1989|. If the GAL4 DNAbinding domain was fused in-frame to TFE3 at a position initiating at amino acid 126, including the entire MSR and leucine zipper (GAL4 $\lambda 3-\Delta 1$ ), only moderate levels of activation were observed $(\sim 10$-fold lower than those found with the intact protein), which did, however, increase as the number of GAL4-binding sites was increased from one to five. In contrast, when the aminoterminal 126 amino acids of the protein were tested (GAL4 $\lambda 3-\Delta 2$ ), extremely high levels of activation resulted $(>1000$-fold). In this case, there was a striking increase in activity when the number of GAL4-binding sites on the reporter plasmid was increased from one to
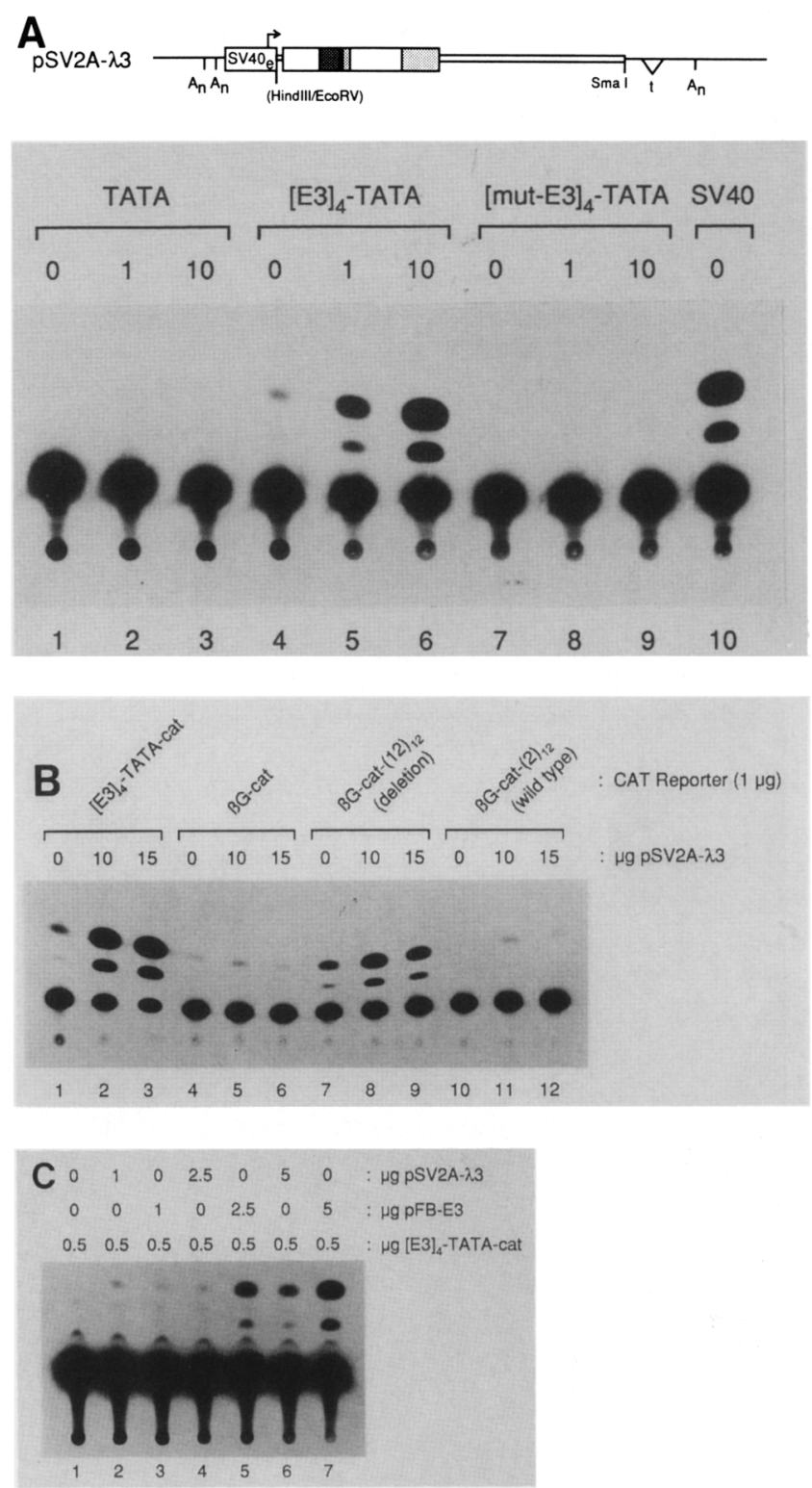

five. Perhaps this dramatic increase reflects cooperative binding of these particular fusion proteins.

The results with the GAL4-TFE3 fusion proteins indicate the presence of a very strong activation domain within the first 126 amino acids of the $\lambda 3$ open reading frame. However, because the TFE3 protein expressed in our pSV2A 33 transfections is also active and begins with the methionine at position 41 , we suspect that the activation domain actually falls between amino acids 41 and 126. When we examined this sequence closely, we noted a region with probable $\alpha$-helical character (Chou and Fassman 1974) with an overall net negative charge of -7. In fact, as diagrammed in Figure 5B, it contains a small polypeptide ( 12 amino acids) that is likely to form a good amphipathic helix with one negative surface and one hydrophobic surface. These types of negative amphipathic helices are thought to define an important 

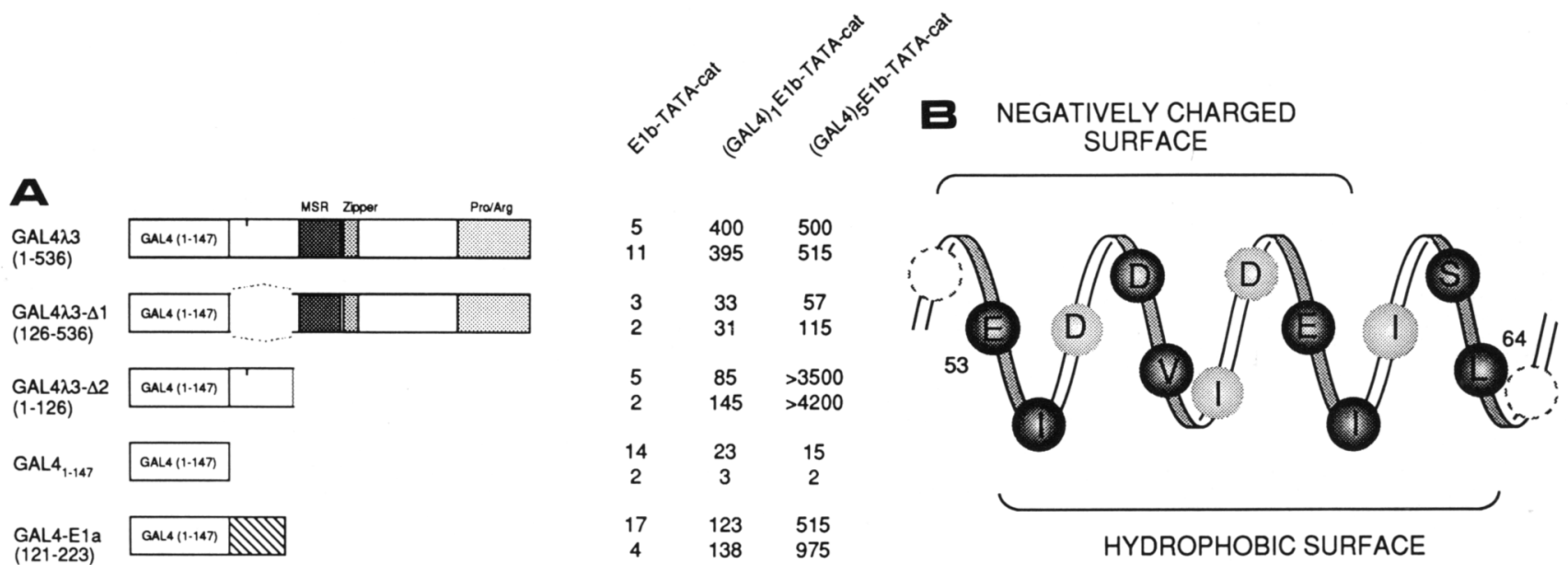

Figure 5. TFE3 contains a strong transcription activation domain. (A) All GAL4-TFE3 fusion plasmids are diagrammed schematically with the encoded amino acids indicated. Plasmid GAL4-ElA bears an activation domain of the adenovirus E1A protein. The reporter plasmids (Lillie and Green 1989) contained the CAT gene linked to an adenovirus E1B promoter TATA box which, in turn, is linked to either no GAL4-binding sites (E1B-TATA-cat), one GAL4-binding site [(GAL4) ${ }_{1}$ E1B-TATA-cat], or five GAL4-binding sites [(GAL4) $)_{5}$ E1B-TATA-cat]. Transfections into 3 T3 cells were carried out using $10 \mu \mathrm{g}$ of each plasmid plus $5 \mu \mathrm{g}$ pCH110. CATase values given are from two separate experiments and expressed in arbitrary units relative to $\beta$-galactosidase activities. $(B)$ Schematic representation of the putative negative amphipathic helix.

class of eukaryotic transcription activation domains (Giniger and Ptashne 1987; Ptashne 1988).

TFE3 is distinct from NF- $\mu E 3$, yet both DNA-binding activities recognize a USF/MLTF motif

To examine the relationship between TFE3 and NF- $\mu \mathrm{E} 3$, we carried out a comparison of the two DNA-binding activities. As a source of TFE3 we employed a full-length protein, $\beta G-\lambda 3$, synthesized in vitro. The in vitro-synthesized $\beta G-\lambda 3$ protein contains all of the amino acids specified by the $\lambda 3$ open reading frame plus an aminoterminal methionine derived from a $\beta$-globin gene segment and an isoleucine encoded by a polylinker fragment (see Methods). As a source of NF- $\mu$ E3-binding activity, we used nuclear extracts prepared from the human B-cell line Namalwa. We carried out mobilityshift assays employing a labeled fragment of the IgH enhancer and a variety of competitor oligonucleotide DNAs. The results are shown in Figure 6. In Namalwa extracts we observed a slow migrating doublet that was sensitive to an oligonucleotide competitor carrying the $\mu$ E3 site (lanes 1 and 2). Competition was not observed with an oligonucleotide carrying a mutant $\mu \mathrm{E} 3$ site (lane 3 ), and identical complexes were observed with a fragment carrying the $\mathrm{kE3}$ site (not shown). Hence, we conclude that this doublet represents NF- $\mu$ E3 activity (Sen and Baltimore 1986). This activity was also sensitive to competition by two different oligonucleotides that bear USF/MLTF-binding sites. The first carries the DNA sequence from the adenovirus major late promoter (USF, lane 5). The second contains a $\mu E 3$ oligonucleotide that was changed at a single base pair to specify a USF/MLTF site $(\mu \mathrm{E} 3 \rightarrow$ USF, lane 6$)$. These results confirm that NF- $\mu$ E3 has a binding specificity similar to that of USF/
MLTF. In vitro-synthesized $\beta G-\lambda 3$ showed the same binding specificity as NF- $\mu$ E3 (lanes 10-14), including the ability to bind to a $\kappa E 3$ site (data not shown).

Complexes formed with $\beta$ G-TFE3 have a slower mobility than those formed with NF- $\mu \mathrm{E} 3$ (cf. Fig. 6, lanes 8 and 10$)$. This is not surprising considering that the $\beta G$ TFE3 protein is calculated to be at least $13 \mathrm{kD}$ larger than NF- $\mu \mathrm{E} 3$ ( 59 versus $42.5-46 \mathrm{kD}$ ). The predicted size of the $\beta$ G-TFE3 protein is consistent with its mobility on SDS-polyacrylamide gels (data not shown). Even if we assume that the $\beta G$-TFE 3 protein represents an artificially large version of TFE3 (i.e., that Met-41 represents the first codon of the normal protein), we would calculate the size of TFE3 to be $\sim 55 \mathrm{kD}$, which is still much larger than NF- $\mu \mathrm{E} 3$.

Although NF- $\mu \mathrm{E} 3$ is the only $\mu \mathrm{E} 3$-binding activity detected in mobility-shift assays with crude nuclear extracts, data that support the existence of an additional, larger $\mu \mathrm{E} 3$-binding protein are shown in Figure 7. HeLa nuclear extracts were resolved by SDS-polyacrylamide gel electrophoresis, transferred to nitrocellulose and exposed to either the wild-type $\mu \mathrm{E} 3$ oligonucleotide [wt oligo (Fig. 7A)] or the mutant $\mu \mathrm{E} 3$ oligonucleotide [mut. oligo (Fig. 7B)]. The filters were subjected to a denaturation/renaturation cycle and probed using exactly the same procedure we used to screen the $\lambda$ gtll cDNA library for TFE3. This experiment identified a 62- to $68 \mathrm{kD}$ protein (bold arrow), and perhaps a slightly larger one (small arrow), that binds specifically to the oligonucleotide carrying the normal $\mu \mathrm{E} 3$ site. Even though the major binding protein is larger than what is known of TFE3, if we consider the resistance of each binding activity to denaturation, that the $\lambda 3 \mathrm{cDNA}$ is not quite full length, and the potential for post-translational modifications, we feel that it probably does represent TFE3. 


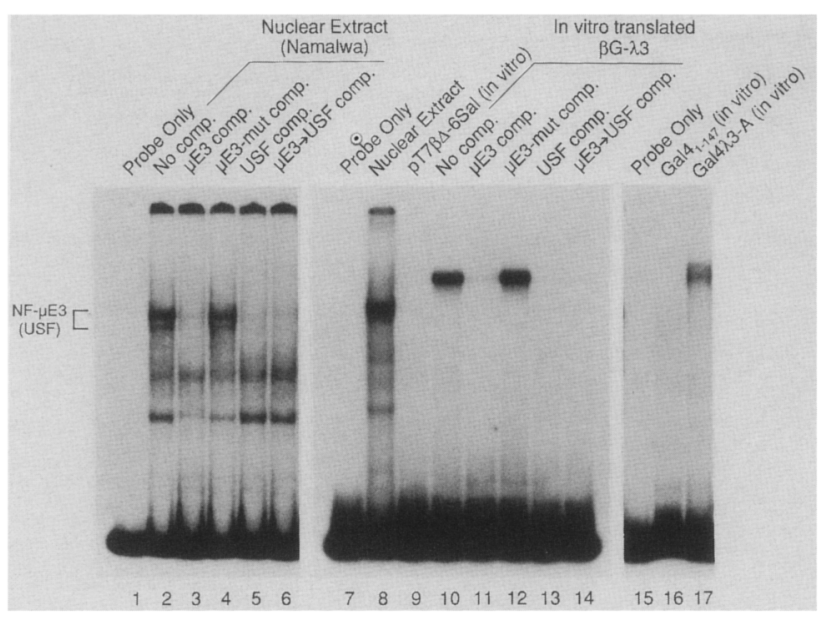

Figure 6. NF- $\mu \mathrm{E} 3$ and TFE 3 synthesized in vitro bind to the USF/MLTF site of the adenovirus major late promoter. Mobility-shift assays used $\mathrm{IgH}$ enhancer fragment 12 as probe and various unlabeled oligonucleotide DNAs as competitors. Assays employed Namalwa nuclear extracts or in vitro-synthesized TFE3 proteins, as indicated (see Methods). (Lanes 1, 7, and 15) Probe alone; (lanes 2 and 8 ) probe plus Namalwa nuclear extract without competitor; (lanes 10,16, and 17) probe plus in vitro-synthesized proteins expressed from TFE3-containing plasmids without competitor; (lane 9) probe plus in vitro-generated protein from the parental plasmid lacking the L3-cDNA (pT7 $\beta \Delta-6 \mathrm{Sal}$ ) without competitor. All other lanes contained probe plus the indicated sources of protein and competitor oligonucleotide DNAs: (Lanes 3 and 11) $\mu \mathrm{E} 3$; (lanes 4 and 12) $\mu \mathrm{E} 3$ mutant; (lane 5 and 13) USF; (lanes 6 and 14) $\mu \mathrm{E} 3 \rightarrow$ USF). The bracket (left) identifies NF- $\mu$ E3- (and possibly USF/MLTF-) binding activity.

\section{Discussion}

We describe here the isolation of a cDNA that encodes TFE3, a positive-acting ubiquitous transcription factor with binding specificity for the $\mu \mathrm{E} 3$ site of the IgH enhancer. The major open reading frame of the cDNA encodes a protein of $59 \mathrm{kD}$ with several interesting putative structural motifs (Johnson and McKnight 1989; Mitchell and Tjian 1989). Among these are two motifs that have been shown for other proteins to facilitate protein-protein interactions. The MSR is thought to specify a helix-loop-helix structure and was initially described in MyoD, a protein involved in myogenic determination (Tapscott et al. 1988). It has now been implicated in a number of different proteins, including two additional myogenic factors, three other immunoglobulin enhancer-binding proteins, a gene associated with a chromosome translocation in a T-cell malignancy, and several Drosophila proteins (Mellentin et al. 1989; Murre et al. 1989a). For the immunoglobulin enhancerbinding proteins, which bind the $\mu \mathrm{E} 5 / \mathrm{kE} 2$ motif, the region encompassing the helix-loop-helix has been shown to mediate DNA-binding through protein homodimer and heterodimer interactions (Murre et al. 1989a; Henthorn et al. 1990). Moreover, the MSRs of otherwise unrelated proteins (such as the $\mathrm{kE}$ 2-binding protein E12 and $\mathrm{MyoD}$ or the Drosophila daughterless protein product) can facilitate the formation of heterodimers that display enhanced DNA-binding affinities (Murre et al. 1989b). Hence, it is possible that the helix-loophelix effectively acts as a regulatory domain and that myc-related helix-loop-helix proteins may modulate one another's activity. In addition to the helix-loophelix, TFE3 contains a putative leucine zipper (Landschulz et al. 1988). The leucine zipper has been found in several transcription factors and has been shown in many cases to mediate function and/or protein-protein interactions, presumably via a coiled-coil structure (O'Shea et al. 1989). One of the more provocative examples of this involves the Fos-Jun interaction, for which both the Fos and Jun leucine zippers are required (Kouzarides and Ziff 1988, 1989; Sassone-Corsi et al. 1988; Gentz et al. 1989; Turner and Tjian 1989). It is possible that the TFE3 leucine zipper also mediates such heterodimer formation, or simply homodimer formation, as found with CCAAT/enhancer-binding protein (C/EBP) (Landschulz et al. 1989). Carboxy-terminal deletions of TFE3 that remove a single leucine reduce DNAbinding drastically $(\mathrm{H}$. Beckmann and $\mathrm{T}$. Kadesch, in prep.). Thus, the TFE3 zipper may indeed facilitate dimerization, if dimerization per se is required for DNAbinding. The location of the TFE3 leucine zipper adjacent to the helix-loop-helix, however, distinguishes it from other zippers that are often found next to basic regions. Perhaps this particular arrangement defines a new class of proteins whose ability to interact /either as homodimers or heterodimers) requires both motifs. The myc proteins may fall into this class, as they also possess leucine zippers.

TFE3 expressed from an SV40 early promoter was found to stimulate transcription in $3 \mathrm{~T} 3$ cells from a pro-

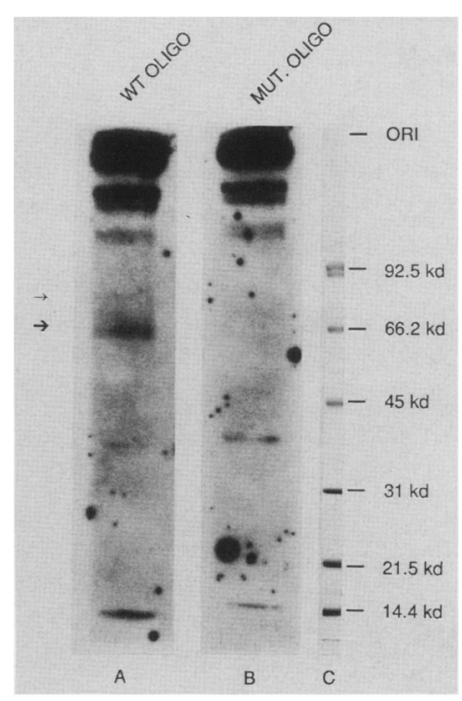

Figure 7. Identification of a $\mu E 3$-binding activity, distinct from NF- $\mu \mathrm{E} 3$. Southwestern analysis of HeLa cell nuclear extracts was carried out as described in Methods. Membranes containing transferred proteins were exposed to $\mu \mathrm{E} 3$ (Lane $A$ ) or mutant- $\mu \mathrm{E} 3$ (Lane $B$ ) oligonucleotide probes. (Lane $C$ ) Stained molecular weight standards. 
moter containing four copies of the $\mu \mathrm{E} 3$ site upstream of a TATA box. This confirms directly that TFE3 is a transcription factor. Cotransfected TFE3 also stimulated transcription in $3 \mathrm{~T} 3$ cells from a transcription unit linked to a subfragment of the IgH enhancer (fragment 12), albeit to a lesser extent. The intact enhancer failed to respond to stimulation by TFE3 in 3T3 cells. Enhancer fragment 12 has been described previously as lacking a negative regulatory domain (Kadesch et al. 1986). Hence, this result is consistent with models that invoke negative regulation as a means of dictating Bcell-specific activity of the enhancer (Kadesch et al. 1986; Wasylyk and Wasylyk 1986; Weinberger et al. 1988). Presumably, the negative regulation works on the $\mu E 3$ motif directly. The relatively low level of TFE3 trans-activation of enhancer fragment 12 compared to that of the $[\mu \mathrm{E} 3]_{4}-$ TATA promoter may simply reflect a copy number effect. Enhancer fragment 12 carries only one copy of the $\mu \mathrm{E} 3$ site. Activation of a $\mu \mathrm{E} 3-\mathrm{TATA}$ promoter with only one $\mu \mathrm{E} 3$ site (as opposed to four) could not be detected in our TFE3 cotransfection experiments (H. Beckmann, L.-K. Su, and T. Kadesch, unpubl.).

We used fusions of GAL4 and TFE3 to map a strong activation domain in the TFE 3 protein. It is located within the amino-terminal 126 amino acids of the protein, a region that is predicted to have some $\alpha$-helical character and bears an overall net negative charge. These features have also been described for the activation domains of several transcription factors, including yeast GAL4 (Ma and Ptashne 1987) and GCN4 (Hope et al. 1988) and the herpesvirus VP16/Vmw65 (Cousens et al. 1989) and papillomavirus E2 proteins (Haugen et al. 1988; Lambert et al. 1989). Studies with model peptides support the idea that a negative amphipathic helix is sufficient for transcription activation /Giniger and Ptashne 1987). In fact, the strong activation domain of TFE3 contains a 12-amino-acid stretch that predicts such a helical structure. Our results also suggest the presence of a second, weaker, activation domain in the protein. We have not yet localized this domain to a specific region of TFE3. Considering what is presently known about transcription-activation domains (Mitchell and Tjian 1989), the proline/arginine-rich region at the carboxyl end would be considered a reasonable candidate (Mermod et al. 1989).

The presence of dimerization motifs in ubiquitous enhancer-binding proteins suggests an attractive model for cell-type-specific regulation. Perhaps TFE3 (and the $\mu \mathrm{E} 5 / \kappa \mathrm{E} 2$ binding proteins as well) functions as a ubiquitous DNA docking protein and transcriptional activation per se (or repression) is mediated through cell-typespecific proteins bound through their helix-loop-helix and/or leucine zipper motifs. This type of model is consistent with both genetic and physical evidence, which support the interplay between the Drosophila proteins daughterless and achaete-scute, both of which contain helix-loop-helix motifs (for further discussion, see Murre et al. $1989 \mathrm{~b}$ and references therein). Our mapping of a strong activation domain in TFE3 outside the helix-loop-helix argues that transcriptional activation per se is not mediated by a separate helix-loop-helix protein. However, it does not preclude models in which TFE3 is negatively regulated (masked?) by other helixloop-helix proteins, perhaps bound at distinct sites on the enhancer.

We propose that TFE3 is not NF- $\mu$ E3. This is based on the difference in the apparent sizes of the two proteins and on our identification of a $\mu E 3$-binding protein in nuclear extracts that is distinct from NF- $\mu$ E3. The open reading frame of the $\lambda 3 \mathrm{cDNA}$ can encode a protein of 59 $\mathrm{kD}$. If Met-41 is the true initiation codon, then TFE3 would be $\sim 55 \mathrm{kD}$. Neither of these estimates is consistent with the sizes of the nuclear proteins that make up NF- $\mu$ E3-binding activity $(42.5-45 \mathrm{kD})$. This difference in size is also reflected by the slower mobility of TFE3 in mobility-shift assays. Moreover, we have detected a $\mu E 3$-binding activity that is distinct from NF $\mu$ E3 in nuclear extracts resolved with SDS-PAGE. The molecular weight of this activity $(62-65 \mathrm{kD})$ is within a range consistent with its being TFE3. The data confirm that the experimental procedure can have a profound influence on the proteins one detects. It appears that NF- $\mu$ E3 activity is sensitive to denaturation/renaturation whereas TFE3 activity is preferentially exposed by such treatment. We have confirmed that a $60-$ to $70-\mathrm{kD}$ protein, and not a $42.5-$ to $45-\mathrm{kD}$ protein, can be detected when HeLa nuclear proteins are resolved by SDS-PAGE, eluted from gel slices, and used in mobility-shift experiments with the $\mu \mathrm{E} 3$ oligonucleotide $(\mathrm{H}$. Beckmann and T. Kadesch, unpubl.).

It is likely that NF- $\mu \mathrm{E} 3$ overlaps with or is equivalent to USF/MLTF. The latter activity has also been described as multiple 43- to 46-kD proteins (Chodosh et al. 1986; Sawadogo et al. 1988). Our experiments demonstrate that NF- $\mu \mathrm{E} 3$ binds very well to a USF/MLTF site, as does TFE3. We cannot say, however, whether TFE3 and USF/MLTF are related functionally because we have not yet been able to activate an adenovirus major late promoter in TFE3 cotransfection experiments (H. Beckmann, L.-K. Su, and T. Kadesch unpubl.). This raises the interesting possibility that TFE3 and USF/MLTF for NF- $\mu$ E3) display similar DNA binding specificities, yet activate transcription of distinct genes. This may provide an example similar to that found with the two octamer binding proteins OTF-1 and OTF-2 (Oct-1 and Oct-2). In this latter instance, the ability of each protein to activate transcription is thought to depend on distinct contexts with regard to additional transcription factors and other DNA binding proteins (Fletcher et al. 1987; Scheidereit et al. 1987; LeBowitz et al. 1988; Muller et al. 1988; Tanaka et al. 1988).

\section{Methods}

Oligonucleotide screening of phage library

A human B-cell-derived $\lambda$ gt11 cDNA library (Clontech) was screened with an $\mu \mathrm{E} 3$ oligonucleotide probe essentially as described by Vinson et al. (1988), with the following modifications. Probe consisted of a $\mu$ E3 oligonucleotide (see below) endlabeled with $\left[\gamma^{-32} \mathrm{P}\right]$ ATP and then ligated to form random concatamers. Nitrocellulose filters bearing transferred phage were 
denatured in buffer $\mathrm{D}[6 \mathrm{M}$ guanidinium hydrochloride, $0.1 \mathrm{M}$ $\mathrm{KCl}, 0.02 \mathrm{M}$ HEPES (pH 7.9), $0.5 \mathrm{~mm}$ dithiothreitol (DTT)] and renatured in buffer $\mathrm{R}$ (buffer $\mathrm{D}$ minus $6 \mathrm{M}$ guanidinium hydrochloride, plus $0.2 \mathrm{mM}$ EDTA). After renaturation the filters were rinsed in buffer $\mathrm{H}[50 \mathrm{~mm}$ Tris $-\mathrm{HCl}(\mathrm{pH} 7.5), 40 \mathrm{mM} \mathrm{NaCl}$ $1 \mathrm{mM}$ EDTA, $1 \mathrm{~mm}$ DTT] and incubated at room temperature for $1 \mathrm{hr}$ in buffer $\mathrm{H}$ supplemented with $5 \%$ nonfat dry milk. The filters were then washed twice in buffer $B$ [10 mM Tris- $\mathrm{HCl}$ (pH 7.5), $40 \mathrm{~mm} \mathrm{NaCl}, 1 \mathrm{~mm}$ EDTA, $1 \mathrm{~mm}$ DTT] and incubated for $1 \mathrm{hr}$ in buffer $\mathrm{B}$ containing labeled oligonucleotide probe $\left(5 \times 10^{5} \mathrm{cpm} / \mathrm{ml}\right)$. Filters were washed for $30 \mathrm{~min}$ with four changes of buffer $B$ and exposed to film.

\section{DNA sequence analyses}

Sequence analyses were performed on single-stranded DNA templates generated from the plasmid pBS- $\lambda 3$ (see below) using the dideoxy chain-termination reaction (Sanger et al. 1977). The sequence was determined on a series of exonuclease III-generated subclones (Henikoff 1987) and by using specific internal primers. The coding region of the $\lambda 3 \mathrm{cDNA}$ was sequenced on both strands.

\section{Synthetic double-stranded oligonucleotides}

The following synthetic oligonucleotides were synthesized by the University of Pennsylvania Cancer Center.

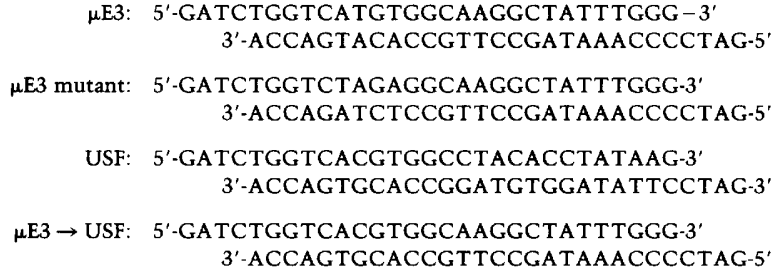

\section{Plasmids}

All plasmids and phage were constructed and manipulated using standard techniques (Maniatis et al. 1982). The 2500-bp $\lambda 3$ cDNA was excised from phage $\lambda 3$ DNA with EcoRI and inserted into the $E c o$ RI site of pBluescript-SK $\mid+$ ) (Stratagene) to create pBS- $\lambda 3$. The plasmid pSV $2 \mathrm{~A}-\lambda 3$ was constructed by excising the $\lambda 3$ cDNA from pBS- $\lambda 3$ with $E c o R V$ and Smal and using it to replace the luciferase gene between HindIII (filled) and SmaI of the plasmid pSV2AL $\Delta 5^{\prime}$ (De Wet et al. 1987). The plasmid pFBE3 was generated by ligating a BgII-HindIII fragment from $\mathrm{p}[\mathrm{E} 3]_{4}$-TATA-CAT (containing the promoter), a $H$ indIII- $B g I I I$ fragment from $\mathrm{pBS}-\lambda 3$ (encoding the amino-terminal portion of the CDNA), and a BglII-BgII fragment from pSV2A- $\lambda 3$ (encoding the carboxy-terminal portion of the $\lambda 3$ cDNA and distal vector sequences). The plasmid containing the TATA box from the liver/bone/kidney alkaline phosphatase gene promoter linked to the bacterial CAT gene, TATA-CAT, and modifications carrying four copies of normal or mutant $\mu \mathrm{E} 3$ oligonucleotides $[\mathrm{E} 3]_{4}-\mathrm{TATA}-\mathrm{CAT}$ and $[\mathrm{mut}-\mathrm{E} 3]_{4}-\mathrm{TATA}-$ CAT, are described in detail elsewhere (M. Kiledjian and T. Kadesch, in prep.; D. Rueszinsky and T. Kadesch, in prep.). The reporter plasmids $\beta$ G-CAT, $\beta$ G-CAT- $(2)_{12}, \beta \mathrm{G}$-CAT- $(12)_{12}$, and pSV2ACAT have been described previously (Kiledjian et al. 1988). All GAL4 fusion proteins were derived from the plasmid pGAL4 $_{1-147}$ (Lillie and Green 1989). GAL4 $\lambda 3$ was constructed by inserting the $\lambda 3 \mathrm{cDNA}$ ( $E c O \mathrm{RI}-E c o \mathrm{RI}$ ) into the $E c o \mathrm{RI}$ site of pGAL4 ${ }_{1-147}$. GAL4 $\lambda 3-\Delta 1$ was generated by inserting a $B g I I I-$ $X b a I$ fragment from the $\lambda 3$ cDNA into pGAL $4_{1-147}$ cut with
$B a m H I$ and $X b a I$. GAL4 $\lambda 3-\Delta 2$ was created by inserting an EcoRI-BgIII fragment from the $\lambda 3$ cDNA into pGAL4 $4_{1-147}$ cleaved with EcoRI and BamHI. In the plasmids GAL $4 \lambda 3$ and GAL4 $\lambda 3-\Delta 1$, the polylinker sequences lead to the insertion of amino acids Pro and Pro-Glu-Phe-Pro-Gly-Ile, between GAL4and $\lambda 3$-encoded amino acids, respectively. In GAL4 $\lambda 3-\Delta 2$, the polylinker leads to the insertion of Pro between GAL4- and $\lambda 3$ encoded sequences and the amino acids Arg-Arg-Arg-Tyr-ProGly-Glu-Phe-Glu-Leu at the carboxyl terminus. The plasmid $\beta G-\lambda 3$ was constructed by ligating the $E c o R V-X b a I$ fragment from pBS- $\lambda 3$ (carrying the entire $\lambda 3$ cDNA), an $X b a I$ to $B g I I$ fragment from pGem 4 (Promega) and a BgII-NcoI (filled) fragment from pT7 $\beta \Delta-6 \mathrm{Sal}$ (Norman et al. 1988). This plasmid carries, in series, a T7 promoter, the 5'-leader and ATG from the human $\beta$-globin gene, one half of an EcoRV site (encoding an isoleucine), and the complete $\lambda 3$ cDNA. Plasmids GAL4 $4_{1-147}$ and GAL4 $43-A$, used for in vitro transcription and translation reactions (see Fig. 6), were constructed by inserting a HindIIIEcoRI fragment from pGAL4 $4_{1-147}$ between the HindIII and EcoRI sites of pGem3 (Promega) and a HindIII-TaqI fragment from GAL $4 \lambda 3$ between the HindIII and AccI sites of pGem 3 .

\section{Preparation of extracts}

Nuclear extracts from HeLa and Namalwa cells were prepared as described by Dignam et al. (1983). Bacterial lysogens of $\lambda \mathrm{gt} 11$ and $\lambda 3$ were grown at $30^{\circ} \mathrm{C}$ to mid-log phase, induced for $30 \mathrm{~min}$ at $42^{\circ} \mathrm{C}$, and grown for $60 \mathrm{~min}$ at $37^{\circ} \mathrm{C}$ in the presence of $10 \mathrm{~mm}$ IPTG. The pellet of a $1-\mathrm{ml}$ culture was resuspended in $100 \mu \mathrm{l}$ buffer D containing $0.5 \mathrm{mM}$ PMSF $\left(4^{\circ} \mathrm{C}\right)$, sonicated, and centrifuged (Eppendorf) for $15 \mathrm{~min}$ at $4^{\circ} \mathrm{C}$. The supernatant was then dialyzed against buffer $\mathrm{R}$ containing $0.1 \% \mathrm{NP}-40$ for $6 \mathrm{hr}$ at $4^{\circ} \mathrm{C}$. Extracts were stored at $-80^{\circ} \mathrm{C}$.

\section{Mobility-shift assays}

Probes were prepared by labeling oligonucleotides or an IgH enhancer fragment either with T4 polynucleotide kinase (New England Biolabs $]$ and $\left[\gamma^{-32} \mathrm{P}\right] \mathrm{ATP}$ or by filling $5^{\prime}$ overhangs with DNA polymerase (Klenow; Promega) and deoxynucleoside triphosphates containing $\left[\alpha-{ }^{32} \mathrm{P}\right] \mathrm{dCTP}$. Probes were separated from unincorporated nucleotides by gel electrophoresis (Maniatis et al. 1982). Enhancer fragment 12 was isolated from pSVAßGCAT-(12) ${ }_{12}$ (Kiledjian et al. 1988), as a XbaI-Xbal fragment. Binding reactions $(0.015 \mathrm{ml})$ generally contained either $10 \mu 1$ lysogen extract $10 \mu \mathrm{g}$ nuclear extract, or $1 \mu \mathrm{l}$ in vitro-translation reaction, 1 fmole double-stranded oligonucleotide 15000 $\mathrm{cpm})$ or $1.3 \mathrm{fmole}$ enhancer fragment $(5000 \mathrm{cpm}), 10 \mathrm{~mm}$ Tris$\mathrm{HCl}(\mathrm{pH} 7.5), 40 \mathrm{mM} \mathrm{NaCl}, 1 \mathrm{~mm} \beta$-mercaptoethanol, $1 \mathrm{~mm}$ EDTA, and $4 \%$ glycerol. In addition, each reaction contained either $100 \mathrm{ng}, 5 \mu \mathrm{g}$, or $500 \mathrm{ng}$ poly[d(I-C)] (Pharmacia, Inc.) when lysogen extracts, nuclear extracts, or in vitro-translated proteins were assayed, respectively. For competition experiments, 1 pmole of unlabeled oligonucleotide was added to the binding reaction prior to the addition of extract. Electrophoresis was carried out using $5 \%$ polyacrylamide gels as described by Singh et al. (1988).

\section{Methylation interference assays}

For methylation interference assays, the 140-bp XbaI-EcoRI IgH enhancer fragment 20 (Kiledjian et al. 1988) was labeled at the $\mathrm{XbaI}$ site with T4 polynucleotide kinase and $\left[\gamma^{-32} \mathrm{P}\right] \mathrm{ATP}$ for analysis of the upper strand (coding) or by filling the $\mathrm{XbaI} 5^{\prime}$ overhang with DNA polymerase (Klenow) and $\left[\gamma^{32}\right.$ P]dCTP for the lower strand (noncoding). The fragment was partially modified by DMS treatment (Maxam and Gilbert 1980) and incubated with $10 \mu \mathrm{l}$ of in vitro-translated protein (GAL4 $\lambda 3-\mathrm{A}$ ) in a 
$30-\mu l$ binding reaction containing $5 \mu \mathrm{g}$ of poly[d(I-C)] for $30 \mathrm{~min}$ at room temperature. After electrophoresis on a nondenaturing gel, the retarded and free bands were treated essentially as described by Chodosh et al. (1988), using $8 \%$ denaturing polyacrylamide gels.

\section{Transfections and CATase assays}

Transfections of mouse NIH-3T3 cells were carried out by calcium phosphate coprecipitation as described by Graham and van der Eb (1973). The amounts of each plasmid used are indicated in the individual figures. Each transfection was carried out two to four times in independent experiments. Levels of $\beta$-galactosidase expression from the plasmid $\mathrm{pCH} 10(5 \mu \mathrm{g}$ per transfection; Lee et al. 1984) were used to determine relative transfection efficiencies and to adjust the amount of extract used for the individual CATase assays (Gorman et al. 1982).

\section{In vitro-transcription and translation reactions}

In vitro transcription with $\mathrm{T} 7$ (Pharmacia) or Sp6 (Promega) RNA polymerase was performed with $1 \mu \mathrm{g}$ linearized DNA templates, essentially as described by Melton et al. (1984). The resulting RNA was translated in a $50-\mu$ l volume containing 35 $\mu l$ of rabbit reticulocyte lysate (Promega), as recommended by the manufacturer.

\section{Southwestern analysis of nuclear proteins}

HeLa cell nuclear extracts $(0.5 \mathrm{mg}$ per lane) were resolved by $10 \%$ SDS-PAGE, and proteins were electrophoretically transferred to a nitrocellulose membrane (Towbin et al. 1979). Membranes were then subjected to a cycle of denaturation and renaturation and exposed to oligonucleotide probes exactly as described above for $\lambda g t 11$ cDNA library screening. Standard protein molecular weight markers were obtained from Sigma.

\section{Acknowledgments}

We thank Ulrike Schindler for supplying encouragement throughout all aspects of this work. We also thank Bob Roeder and members of his laboratory for pointing out the relationship between the $\mu \mathrm{E} 3$ and USF/MLTF binding sites, and Kathryn Calame for additional comments concerning the sequence of the TFE3 protein. Finally, we thank the members of the Kadesch lab for reagents and helpful discussion. This work was supported by funds from the Howard Hughes Medical Institute. H.B. was supported by a grant from the Deutscher Akademischer Austauschdienst DAAD, Sonderprogramm Gentechnologie.

\section{Note added in proof}

Recently Roeder et al. (pers. comm.) isolated a cDNA that potentially encodes USF/MLTF. The cDNA encodes a protein of roughly $40-45 \mathrm{kD}$, which binds to both the USF/MLTF site of the adenovirus major late promoter and the $\mu \mathrm{E} 3$ site of the IgH enhancer. Sequence comparison of their cDNA and that encoding TFE 3 indicates that the two CDNAs are derived from distinct genes. Considering the likelihood that USF/MLTF and NF- $\mu$ E3 represent the same DNA binding activity, the existence of their cDNA offers further support that TFE3 is not related to NF- $\mu \mathrm{E} 3$.

\section{References}

Atchinson, M.L. 1988. Enhancers: Mechanisms of action and cell specificity. Annu. Rev. Cell Biol. 4: 127-153.

Banerii, J., L. Olson, and W. Schaffner. 1983. A lymphocyte-specific cellular enhancer is located downstream of the joining region in immunoglobulin heavy chain gene. Cell 33: 729740.

Battey, J., C. Moulding, R. Taub, W. Murphy, T. Stewart, H. Potter, G. Lenoir, and P. Leder. 1983. The human c-myc oncogene: Structural consequences of translocation into the IgH locus in Burkitt lymphomas. Cell 34: 779-787.

Beckmann, H. and T. Kadesch. 1989. Identification of a yeast protein with properties similar to those of the immunoglobulin heavy-chain enhancerbinding protein NF- $\mu$ E3. Mol. Cell. Biol. 9: 4535-4540.

Calame, K. and S. Eaton. 1988. Transcriptional controlling elements in the immunoglobulin and T cell receptor loci. Adv. Immunol. 43: 235-275.

Chodosh, L.A., R.W. Carthew, and P.A. Sharp. 1986. A single polypeptide possesses the binding and transcription activities of the adenovirus major late transcription factor. Mol. Cell. Biol. 6: 4732-4733.

Chodosh, L.A., A.S. Baldwin, R.W. Carthew, and P.A. Sharp. 1988. Human CCAAT-binding proteins have heterologous subunits. Cell 53: 11-24.

Chou, P.Y., and G.D. Fassman. 1974. Conformational parameters for amino acids in helical, $\beta$-sheets, and random coil regions calculated from proteins. Biochemistry. 13: $211-$ 222.

Cousens, D.I., R. Greaves, C.R. Goding, and P. O'Hare. 1989. The Cterminal 79 amino acids of the herpes simplex virus regulatory protein, Vmw65, efficiently activate transcription in yeast and mammalian cells in chimeric DNAbinding proteins. EMBO J. 8: 2337-2342.

Davis, R.L., H. Weintraub, and A.B. Lassar. 1987. Expression of a single transfected cDNA converts fibroblasts to myoblasts. Cell 51: 987-1000.

De Wet, J.R., K.V. Wood, M. DeLuca, D.R. Helinski, and S. Subramani. 1987. Firefly luciferase gene: Structure and expression in mammalian cells. Mol. Cell. Biol. 7: 725-737.

Dignam, J.D., R.M. Lebowitz, and R.G. Roeder. 1983. Accurate transcription initiation by RNA polymerase II in a soluble extract from isolated mammalian nuclei. Nucleic Acids Res. 11: 1475-1489.

Ephrussi, A., G.M. Church, S. Tonegawa, and W. Gilbert. 1985. B lineagespecific interactions of a immunoglobulin enhancer with cellular factors in vivo. Science 227: 134-140.

Fletcher, C., N. Heintz, and R. Roeder. 1987. Purification and characterization of OTF-1, a transcription factor regulating cell cycle expression of a human histone $\mathrm{H} 2 \mathrm{~b}$ gene. Cell 51: 773-781.

Gentz, R., F.J. Rauscher III, C. Abate, and T. Curran. 1989. Parallel association of Fos and Jun leucine zippers juxtaposes DNA-binding domains. Science 243: 1695-1699.

Gerster, T., P. Matthias, M. Thali, J. Jiricny, and W. Schaffner. 1987. Cell type-specificity elements of the immunoglobulin heavy-chain gene enhancer. $E M B O$ /. 6: 1323-1330.

Gillies, S.D., S.L. Morrison, V.T. Oi, and S. Tonegawa. 1983. A tissue specific transcription enhancer element is located in the major intron of immunoglobulin heavy-chain gene. Cell 33: $717-728$.

Giniger, E., and M. Ptashne. 1987. Transcription in yeast activated by a putative amphipathic $\alpha$ helix linked to DNAbinding unit. Nature 330: 670672 . 
Graham, F.L., and A.J. van der Eb. 1973. A new technique for the assay of infectivity of human adenovirus 5 DNA. Virology 52: 456-467.

Gorman, C.M., L.F. Moffat, and B.H. Howard. 1982. Recombinant genomes which express chloramphenicol acetyltransferase in mammalian cells. Mol. Cell. Biol. 2: 1044-1051.

Haugen, T.H., L.P. Turek, F.M. Mercurio, T.P. Cripe, B.J. Olson, R.D. Anderson, D. Seidl, M. Karin, and J. Schiller. 1988. Sequencespecific and general transcriptional activation by the bovine papillomavirus-1 $\mathrm{E} 2$ trans-activator require an $\mathrm{N}$-terminal amphipathic helixcontaining E2 domain. EMBO $/$. 7: 4245-4253.

Henikoff, S. 1987. Unidirectional digestion with exonuclease III in DNA sequence analysis. Meth. Enzymol. 155: 156-165.

Henthorn, P., M. Kiledjian, and T. Kadesch. 1990. Two transcription factors that bind the immunoglobulin enhancer $\mu \mathrm{E} 5 / \mathrm{kE} 2$ motif. Science (in press).

Hope, I.A., S. Mahadevan, and K. Struhl. 1988. Structural and functional characterization of the short acidic transcriptional activation region of yeast GCN4 protein. Nature 333: 635-640.

Imler, J.-L., C. Lemaire, C. Wasylyk, and B. Wasylyk. 1987. Negative regulation contributes to tissue specificity of the immunoglobulin heavychain enhancer. Mol. Cell. Biol. 7: $2558-2567$.

Johnson, P.F., and S.L. McKnight. 1989. Eukaryotic transcriptional regulatory proteins. Annu. Rev. Biochem. 58: 799839.

Kadesch, T., P. Zervos, and D. Ruezinsky. 1986. Functional analysis of the murine $\mathrm{IgH}$ enhancer: evidence for negative control of cell-type specificity. Nucleic Acids Res. 14: 8209-8221.

Keegan, L., G. Gill, and M. Ptashne. 1986. Separation of DNA binding from the transcription-activating function of a eukaryotic regulatory protein. Science 231: 699-704.

Kiledjian, M., L.-K. Su, and T. Kadesch. 1988. Identification and characterization of two functional domains within the murine heavy-chain enhancer. Mol. Cell. Biol. 8: 145-152.

Kouzarides, T. and E. Ziff. 1988. The role of the leucine zipper in the fos-jun interaction. Nature 336: 646-651.

1989. Leucine zippers of fos, jun, and GCN4 dictate dimerization specificity and thereby control DNAbinding. Nature 340: 568-571.

Kozak, M. 1984. Compilation and analysis of sequences upstream from the translational start site in eukaryotic mRNAs. Nucleic Acids Res. 12: 857-872.

Lambert, P.F., N. Dostatni, A.A. McBride, M. Yaniv, P.M. Howley, and B. Arcangioli. 1989. Functional analysis of the papillomavirus E2 transactivator in Saccharomyces cerevisiae. Genes Dev. 3: 38-48.

Landolfi, N.F., J.D. Capra, and P.W. Tucker. 1986. Interaction of celltype-specific nuclear proteins with immunoglobulin $\mathrm{V}_{\mathrm{H}}$ promoter region sequences. Nature 323: 548-551.

Landschulz, W.H., P.F. Johnson, and S.L. McKnight. 1988. The leucine zipper: A hypothetical structure common to a new class of DNA-binding proteins. Science 240: 1759-1732.

- 1989. The DNA-binding domain of the rat liver nuclear protein C/EBP is bipartite. Science 230: 1681-1688.

LeBowitz, J.H., T. Kobayashi, L. Staudt, D. Baltimore, and P.A.Sharp. 1988. Octamer-binding proteins from B or HeLa cells stimulate transcription of the immunoglobulin heavychain promotor in vitro. Genes Dev. 2: 1227-1237.

Lee, F., C.V. Hall, G.M. Ringold, D.E. Dobson, J. Luh, and P.E. Jacob. 1984. Functional analysis of the steroid hormone control region of the mouse mammary tumor virus. Nucleic Acids Res. 12: 4191-4206.
Lenardo, M., J.W. Pierce, and D. Baltimore. 1987. Proteinbinding sites in Ig gene enhancers determine transcriptional activity and inducibility. Science 236: 1573-1577.

Lillie, J.W. and M.R. Green. 1989. Transcription activation by the adenovirus E1a protein. Nature 338: 39-44.

Ma, J., and M. Ptashne. 1987. Deletion analysis of GAL4 defines two transcriptional activating segments. Cell 48: 847-853.

Maniatis, T., E.F. Fritsch, and J. Sambrook. 1982. Molecular cloning. A laboratory manual. Cold Spring Harbor Laboratory Press, Cold Spring Harbor, New York.

Maxam, A. and W. Gilbert. 1980. Sequencing end-labeled DNA with basespecific chemical cleavages. Methods. Enzymol. 65: 499-560.

Mellentin, J.D., S.D. Smith, and M.L. Cleary. 1989. 1yl-1, a novel gene altered by chromosomal translocation in $\mathrm{T}$ cell leukemia, codes for a protein with a helix-loop-helix DNA-binding motif. Cell 58: 77-83.

Melton, D.A., P.A. Krieg, M.R. Ribagliati, T.P. Maniatis, K. Zinn, and M.R. Green. 1984. Efficient in vitro synthesis of biologically active RNA and RNA hybridization probes from plasmids containing a bacteriophage SP6 promotor. Nucleic Acids Res. 12: 7035-7056.

Mermod, N., E.A. O'Neill, T.J. Kelly, and R. Tjian. 1989. The prolinerich transcriptional activator of CTF/NF-1 is distinct from the replication and DNA-binding domain. Cell 58: $741-753$.

Mitchell, P.J. and R. Tjian. 1989. Transcriptional regulation in mammalian cells by sequence-specific DNA-binding proteins. Science 245: 371-378.

Muller, M.M., S. Ruppert, W. Schaffner, and P. Matthias. 1988. A cloned octamer transcription factor stimulates transcription from lymphoid-specific promoters in non-B cells. $\mathrm{Na}$ ture 336: 544-551.

Murre, C., P. Schonleber McCaw, and D. Baltimore. 1989a. A new DNA-binding and dimerization motif in immunoglobulin enhancer binding, daughterless, MyoD, and myc proteins. Cell 56: 777-783.

Murre, C., P. Schonleber McCaw, H. Vaessin, M. Caudy, L.Y. Jan, Y.N. Jan, C.V. Cabrera, J.N. Buskin, S.D. Hauschka, A.B. Lassar, H. Weintraub, and D. Baltimore. 1989b. Interactions between heterologous helix-loop-helix proteins generate complexes that bind specifically to a common DNA sequence. Cell 58: 537-544.

Neuberger, M.S. 1983. Expression and regulation of immunoglobulin heavy-chain genes transfected into lymphoid cells. $E M B O$ /. 2: 1373-1378.

Norman, C., M. Runswick, R. Pollock, and R. Treisman. 1988. Isolation and properties of cDNA clones encoding SRF, a transcription factor that binds to the c-fos serum response element. Cell 55: 989-1003.

O'Shea, E.K., R. Rutkowski, and P.S. Kim. 1989. Evidence that the leucine zipper is a coiled coil. Science 243: 538-542.

Perez-Mutul, J., M. Macchi, and B. Wasylyk. 1988. Mutational analysis of the contribution of sequence motifs within the IgH enhancer to tissue specific transcriptional activation. Nucleic Acids Res. 16: 6085-6096.

Peterson, C.L. and K. Calame. 1987. Complex protein binding within the mouse immunoglobulin heavy-chain enhancer. Mol. Cell. Biol. 7: 4194-4203.

Peterson, C.L., S. Eaton, and K. Calame. 1988. Purified $\mu$ EBP-E binds to immunoglobulin enhancers and promoters. Mol. Cell. Biol. 8: 4972-4980.

Peterson. C.L. and K. Calame. 1989. Proteins binding to site C2 $(\mu \mathrm{E} 3)$ in the immunoglobulin heavy-chain enhancer exist in multiple oligomeric forms. Mol. Cell. Biol. 9: 776-786.

Ptashne, M. 1988. How eukaryotic transcriptional activators 
work. Nature 335: 683-689.

Sanger, F., S. Nicklen, and A.R. Coulson. 1977. DNA sequencing with chain-terminating inhibitors. Proc. Natl. Acad. Sci. 74: 5463-5467.

Sassone-Corsi, P., L.J. Ransone, W.W. Lamph, and I.M. Verma. 1988. Direct interaction between fos and jun nuclear oncoprotein: Role of the 'leucine zipper' domain. Nature 336: $692-695$.

Sawadogo, M., M.W. Van Dyke, P.D. Gregor, and R.G. Roeder. 1988. Multiple forms of the human gene-specific transcription factor USF. J. Biol. Chem. 263: 11985-11993.

Scheidereit, C., A. Heguey, and R.G. Roeder. 1987. Identification and purification of a human lymphoid-specific octamer binding protein (OTF-2) that activates transcription of an immunoglobulin promoter in vitro. Cell 51: 783-793.

Scholer, H.R., A.K. Hatzopoulos, R. Balling, N. Suzuki, and P. Gruss. 1989a. A family of octamer-specific proteins present during mouse embryogenesis: Evidence for germ line-specific expression of an oct factor. EMBO I. 8: 2543-2550.

Scholer, H.R., R. Balling, A.K. Hatzopoulos, N. Suzuki, and P. Gruss. 1989b. Octamer binding proteins confer transcriptional activity in early mouse embryogenesis. $E M B O \%$. 8: $2551-1557$.

Schreiber, E., P. Matthias, M.M. Muller, and W. Schaffner. 1988. Identification of a novel lymphoid specific octamer binding protein (OTF-2B) by proteolytic clipping bandshift assay (PCBA). EMBO I. 7: 4221-4229.

Sen, R. and D. Baltimore. 1986. Multiple nuclear factors interact with the immunoglobulin enhancer sequences. Cell 46: $705-716$.

Singh, H., J.H. LeBowitz, A.S. Baldwin, and P.A. Sharp. 1988. Molecular cloning of an enhancer binding protein: Isolation by screening of an expression library with a recognition site DNA. Cell 52: 415-423.

Singh, H., R. Sen, D. Baltimore, and P.A. Sharp. 1986. A nuclear factor that binds to a conserved sequence motif in transcriptional control elements of immunoglobulin genes. Nature 319: $154-158$.

Staudt, L.M., H. Singh, R. Sen, T. Wirth, P.A. Sharp, and D. Baltimore. 1986. A lymphoid-specific protein binding to the octamer motif of immunoglobulin genes. Nature 323: 640643.

Sturm, R.A., G. Das, and W. Herr. 1988. The ubiquitous octamer-binding protein Oct- 1 contains a POU domain with a homeo box subdomain. Genes Dev. 2: 1582-1599.

Tanaka, M., U. Grossniklaus, W. Herr, and N. Hernandez. 1988. Activation of the U2 snRNA promotor by the octamer motif defines a new class of RNA polymerase II enhancer elements. Genes Dev. 2: 1764-1778.

Tapscott, S.J., R.L. Davis, M.J. Thayer, P.F. Cheng, H. Weintraub, and A.B. Lassar. 1988. MyoD: A nuclear phosphoprotein requiring a myc homology region to convert fibroblasts to myoblasts. Science 242: 405-411.

Towbin, H., T. Staehelin, and J. Gordon. 1979. Electrophoretic transfer of proteins from polyacrylamide gels to nitrocellulose sheets: Procedure and some applications. Proc. Natl. Acad. Sci. 76: 4350-4354.

Tsao, B.P., X.-F. Wang, C.L. Peterson, and K. Calame. 1988. In vivo functional analysis of in vitro protein binding sites in the immunoglobulin heavy-chain enhancer. Nucleic Acids Res. 16: 3239-3253.

Turner, R. and R. Tjian. 1989. Leucine repeats and adjacent DNA-binding domain mediate the formation of functional cFos-cJun heterodimers. Science 243: 1689-1694.

Vinson, C.R., K.L. LaMarco, P.R. Johnson, W.H. Landschulz, and S.L. McKnight. 1988. In situ detection of sequence-spe- cific DNA-binding activity specified by a recombinant bacteriophage. Genes Dev. 2: 801-806.

Wasylyk, C. and B. Wasylyk. 1986. The immunoglobulin heavy-chain Blymphocyte enhancer efficiently stimulates transcription in non-lymphoid cells. EMBO J. 5: 553-560.

Weinberger, J., P.S. Jan, and P.A. Sharp. 1988. Localization of a repressive sequence contributing to B-cell specificity in the immunoglobulin heavy-chain enhancer. Mol. Cell. Biol. 8: $988-992$.

Weiss,M.J., K. Ray, P.S. Henthorn, B. Lamb, T. Kadesch, and H. Harris. 1988. Structure of the human liver/bone/kidney alkaline phosphatase gene. J. Biol. Chem. 263: 12002-12010.

Wright, W.E., D.A. Sasson, and V.K. Lin. 1989. Myogenin, a factor regulating myogenesis, has a domain homologous to MyoD. Cell 56: 607-617. 


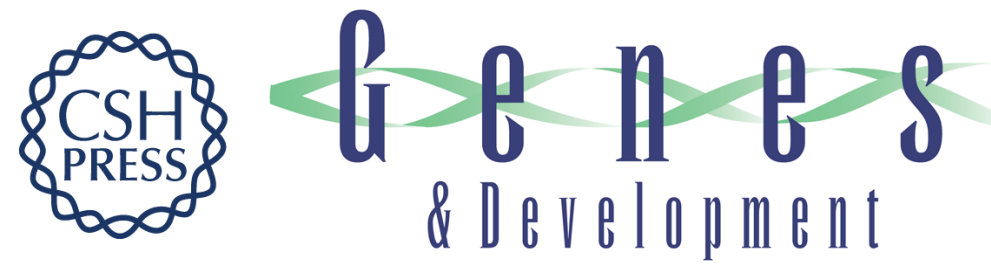

\section{TFE3: a helix-loop-helix protein that activates transcription through the immunoglobulin enhancer muE3 motif.}

H Beckmann, L K Su and T Kadesch

Genes Dev. 1990, 4:

Access the most recent version at doi:10.1101/gad.4.2.167

References This article cites 78 articles, 27 of which can be accessed free at:

http://genesdev.cshlp.org/content/4/2/167.full.html\#ref-list-1

License

Email Alerting

Service

Receive free email alerts when new articles cite this article - sign up in the box at the top right corner of the article or click here.

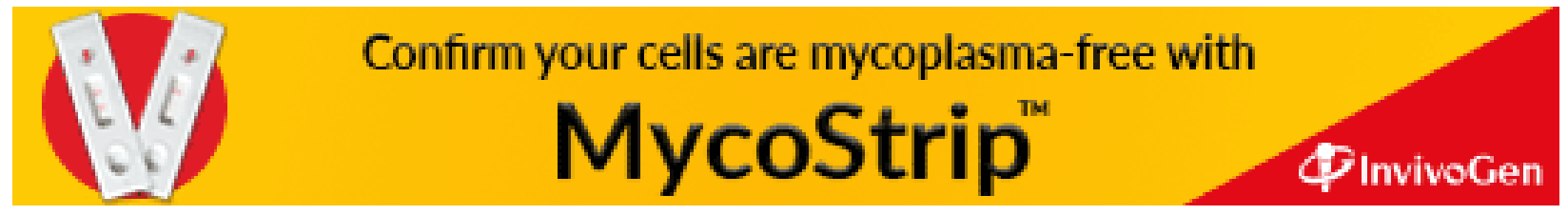

